Historia Slavorum Occidentis

2021, nr 4 (31)

ISSN 2084-1213

DOI: $10.15804 /$ hso210412

Piotr Okulewicz (PoznaŃ)

ORCID: 0000-0001-5927-9737

\title{
Świat współczesny widziany oczyma Jacques'a Perettiego (Zakulisowe umowy, które zmieniły świat. Niepohamowane ambicje, tajne negocjacje i skrywane prawdy w biznesie, Poznań 2019, ss. 359)
}

Jacques Peretti, absolwent London School of Economics, jest doświadczonym dziennikarzem śledczym. W latach dziewięćdziesiątych był zatrudniony w BBC m.in. jako komentator parlamentarny, a później jako reporter nagradzanych serii dokumentalnych poruszających problemy przemian cywilizacyjnych współczesnego świata - konsumpcjonizmu, otyłości, mody na atrakcyjną sylwetkę, wpływu osób posiadających wielkie fortuny na życie przeciętnego obywatela czy marnotrawstwa w gospodarowaniu państwowymi funduszami przez administrację państwową. Efekty jego poszukiwań możemy śledzić w takich produkcjach, jak: „Superbogaci i my”, „Kto nas tuczy”, „Ludzie, którzy zmusili nas do wydawania pieniędzy”, „Kajmany. Ukryte miliony”. Swoje obserwacje i refleksje przelał również na papier, publikując dwie prace: Done: The Billion Dollar Deals and How They're Changing Our World (2017) oraz The Deals That Made the World (2018). Druga z nich, dzięki thumaczeniu Bożeny Jóźwiak, trafiła niedawno na półki księgarń.

Książka Perettiego, wbrew temu, co może sugerować tytul, nie jest kolejną sensacyjną opowieścią, lansującą jeszcze jedną teorię spiskową. W rzeczywistości autor, korzystając z zebranego materiału bibliograficznego i przeprowadzonych rozmów, 
podjął się próby opisania procesów i zmian gospodarczych, jakim podlega współczesny świat w ostatnich dekadach. Zakulisowe umowy, na kanwie których autor oparł swoją opowieść, zawarto z różnych pobudek. Czasami były one podyktowane próbą ochrony branży przed skutkami wielkiego kryzysu ekonomicznego, niekiedy zainicjowano je przypadkiem, na przykład rozpaczliwie broniąc się przed zwolnieniem z pracy, lub były efektem nowatorskich i niekonwencjonalnych wizji ich inicjatorów. Jednak we wszystkich dziesięciu opisanych przez autora przypadkach rozpoczęły one liczne zmiany, które miały rewolucyjny wpływ na dalszy rozwój globalnej gospodarki, a przez to również bezpośrednio na nasze życie.

Już we wstępie autor zwraca uwagę na to, że od czasu załamania się systemu w Bretton Woods w 1971 r., czyli od momentu zniesienia gwarantowanych przez rządy poszczególnych państw stałych kursów walut, odnotowujemy stały wzrost znaczenia międzynarodowych korporacji. Zyskiwały one coraz większą władzę, nie musiały już bowiem wchodzić w porozumienie z rządami poszczególnych państw, a ich strategiczne decyzje wynikały i nadal wynikają z sytuacji geopolitycznej. „Staje się to oczywiste nawet przy przelotnym rzucie oka na mapę świata. Dziecku mógłby się on [świat - P.O.] wydać pięknie uporządkowany, z krajami w żywych kolorach starannie oddzielonymi granicami. W pewnym sensie taka mapa jest prawidłowa, gdyż rządy kierują swoimi państwami pionowo w wytyczonych granicach. Ich działalność w dużej mierze dotyczy jednak własnego podwórka, a tym samym nieraz mają mniejsze wpływy geopolityczne niż korporacje działające na całym globie, bez zwracania szczególnej uwagi na kolory. [... ] Żyjemy w czasach globalizacji, ale mimo to dalej błędnie postrzegamy nasz świat w sposób sprzed tej ery, traktując polityków i rządy jako jedyne ośrodki władzy"1. Przedstawiana praca składa się z dziesięciu rozdziałów poświęconych różnym procesom zachodzącym w światowej gospodarce, dla których pretekstem stały się zakulisowe rozmowy i porozumienia zawierane między właścicielami wielkich organizacji gospodarczych. I chociaż narrację Perettiego w wielu miejscach można uzupełnić i znacznie rozszerzyć, to stanowi ona punkt wyjścia do głębszej refleksji nad stanem naszej cywilizacji.

Peretti rozpoczyna swoją opowieść od omówienia procesów, które dopiero od niedawna zaczęły skupiać na sobie uwagę klientów sklepów i salonów, a stają się coraz poważniejszym problemem dla każdego konsumenta żyjącego w kraju o wysokim stopniu rozwoju gospodarczego. W ostatnich latach jesteśmy regularnie

1 J. Peretti, Zakulisowe umowy, które zmienity świat. Niepohamowane ambicje, tajne negocjacje i skrywane prawdy w biznesie, Poznań 2019, s. 13. 
atakowani przez wszechobecną reklamę narzucającą konieczność posiadania kolejnych, „jeszcze lepszych”, „jeszcze bardziej niezawodnych”, „niezbędnych do życia” i „pozwalających być człowiekiem nowoczesnym” nowszych wersji poszczególnych przedmiotów codziennego użytku. Dlatego pierwszy rozdział został poświęcony szerzonemu w ostatnich czasach kultowi nowszych serii, wersji czy odmian produktów, które co jakiś czas pojawiają się w sprzedaży. Pretekstem do omówienia tego zjawiska stało się porozumienie zawarte w środku wielkiego kryzysu ekonomicznego - w 1932 r. - przez największych producentów żarówek. Tajny układ miał ratować rynek zbytu tego produktu (a tym samym istniejące zakłady i miejsca pracy) przez pogorszenie jakości produkowanych żarówek. Bardzo dokładnie określono, w których elementach żarówki zamontuje się wadliwe elementy, by skrócić ich żywot i zmusić klientów do zakupu nowych. Peretti śledzi dalsze losy tego porozumienia (a raczej idei w nim zawartej), pokazując procesy skłaniające producentów innych branż do przyswojenia sobie filozofii kształtowania rynku zbytu, a w późniejszym czasie do kształtowania, a nawet sterowania gustami i upodobaniami potencjalnych klientów. Dzisiaj praktyka opisana w pierwszym rozdziale jest tak daleko posunięta, że obejmuje praktycznie wszystkie sprzęty użytkowe. Gdy niedawno przyjechatem do warsztatu samochodowego, prowadzonego przez znajomego mechanika z uszkodzonym sprzęgłem, ten zaoferował mi z miejsca wymianę kolejnego - jeszcze sprawnego - elementu sprzęgła. Twierdzil, że za dwa-trzy tygodnie i tak powrócę do jego warsztatu. Wymieniając ten element razem ze sprzęgłem, zaoszczędzę czas i pieniądze, a on nie będzie musiał dwa razy rozbierać na części samochodu. Proces ten jest tak daleko posunięty, że mechanicy licytują się obecnie, z jaką dokładnością są w stanie określić czas kolejnej wizyty klienta w warsztacie.

Drugi rozdział rozpoczyna się z kolei od prowokacyjnego pytania: „Co widzisz, przechadzając się po supermarkecie? Całe ściany wysokokalorycznych i wysokoprzetworzonych produktów ulepszonych chemicznie dla bardziej wyrazistego smaku i «powtarzalnego zainteresowania» (co jest naukowym określeniem właściwości uzależniających). Czysta nauka na talerzu. A w alejkach obok? Długie rzędy żywności niskotłuszczowej, light, chudej, dietetycznej, zero, niskowęglowodanowej, niskokalorycznej, bez cukru i tak zwanej «zdrowej», kierowanej do tych samych klientów, którzy utuczyli się produktami z sąsiedniej części sklepu i teraz rozpaczliwie starają się zrzucić nadmiar wagi”2. Źródłem tego szaleństwa stała się nowa interpretacja wskaźnika BMI z 1945 r., która została zaakceptowana przez lekarzy

2 Tamże, s. 33-34. 
i farmaceutów w całych Stanach Zjednoczonych. Na czym ona polegała? Otóż jej twórca, pracownik Metropolitan Life (MetLife) Louis Dublin zauważył, że wysokość składek ubezpieczeniowych jest zależna od masy ciała klientów. Wpadł więc na pomysł, by obniżyć progi, od których zaczyna się nadwaga i otyłość. Do naukowego uzasadnienia podjętych decyzji posłużono się wskaźnikiem BMI, chociaż już wtedy zdawano sobie sprawę z jego wadliwości. Nie uwzględniał bowiem różnicy pomiędzy masą mięśniową a tłuszczową. Dublin jednak pominął ten aspekt i przyjął arbitralnie za prawidłową, bez żadnego uzasadnienia merytorycznego, masę ciała dwudziestopięciolatka. W jednej chwili wielu Amerykanów stało się obywatelami zagrożonymi otyłością. To z pozoru błahe wydarzenie na przestrzeni kolejnych dziesięcioleci zainicjowało cały szereg kolejnych decyzji, które w efekcie doprowadziły do katastrofalnych dla naszego zdrowia konsekwencji, m.in. pojawienia się wszechobecnej otyłości.

I wreszcie w trzecim rozdziale Peretti przedstawił splot wydarzeń, które uczyniły znaczną część społeczeństwa lekomanami i mają niebagatelny wpływ na stan naszego zdrowia i życia. Warto zwrócić uwagę na ten rozdział choćby dlatego, że Polacy znajdują się w światowej czołówce ofiar tych przemian. Chodzi o propozycję złożoną w 1980 r. branży farmaceutycznej przez prezesa firmy Merck, a dotyczącą zwiększenia liczby pacjentów, którym będzie można przepisywać leki na receptę, by poradzić sobie z potencjalnym kryzysem po wygaśnięciu patentów na najbardziej zyskowne produkty.

Peretti, opisując procesy zachodzące w tej gałęzi przemysłu, cofnął się w swej narracji do czasów powstania w 1862 r. w Stanach Zjednoczonych Agencji Żywności i Leków (FDA). To ona otrzymała prawo decydowania o dopuszczaniu kolejnych leków do powszechnego obrotu. Przez kolejne dekady FDA stosowała długotrwałą i skrupulatną procedurę dopuszczania leków na rynek. Ta praktyka doprowadziła ostatecznie do wysunięcia przez firmy farmaceutyczne oskarżenia, że agencja odmawia Amerykanom prawa do korzystania z najnowszych osiągnięć przemysłu farmaceutycznego. W odpowiedzi na te zarzuty w $1980 \mathrm{r}$. przegłosowano ustawę, która w ostateczności stała się furtką dla producentów leków. Umożliwiała ona uczelniom i organizacjom non profit uzyskanie patentu na konkretne projekty lub wynalazki. Wydawało się, że uczelnie odtąd będą mogły skutecznie konkurować $\mathrm{w}$ dziedzinie produkcji lekarstw z koncernami farmaceutycznymi. W rzeczywistości nowe prawo przyczyniło się wykształcenia swoistej współpracy na linii koncerny-uczelnie. Firma opracowywała nowy lek, a uczelnia rzekomo niezależnie testowała go w jej imieniu i ostrzegała przed możliwymi zarzutami ze strony FDA. 
W ten sposób zainteresowani stworzyli system obchodzenia zabezpieczeń prawnych chroniących przed dopuszczaniem do obrotu leków nieprzetestowanych. Jednym ze skutków stosowania takich praktyk było umocnienie się relacji finansowych między uniwersytetami a branżą farmaceutyczną. Uczelnie otrzymywały pieniądze na badania, które później służyły wspieraniu wniosków o rejestracje leków tych przedsiębiorstw przed komisjami FDA ${ }^{3}$. Ważnym etapem w rozwoju rynku farmaceutycznego w USA było coraz częstsze emitowanie reklam w formule DTC (direct-toconsumer), które były skierowane nie do lekarzy czy farmaceutów, ale wprost do pacjentów. Pozwoliło to znacznie poszerzyć zakres odbiorców reklam i pośrednio wywierać za ich pomocą presję na lekarzy, by przepisywali określony specyfik pacjentom.

Firmy farmaceutyczne korzystały jeszcze z dwóch innych wybiegów, mających zwiększyć dochody ze sprzedaży leków. Pierwszym z nich jest nadal stosowane tworzenie nowych chorób lub poszerzanie zakresu definicji poszczególnych schorzeń. $\mathrm{W}$ ostatnich dekadach dowiedzieliśmy się o istnieniu wielu dotąd nieznanych przypadłości, przy czym szczególne wrażenie robi przytoczona przez Perettiego ewolucja takiej cechy naszego zachowania jak nadpobudliwość. Po raz pierwszy została opisana w 1798 r. i określono ją jako „niepokój psychiczny”. W USA od 1952 r. co jakiś czas wydawany jest Diagnostyczny i statystyczny podręcznik zaburzeń psychicznych, który pozwala powiązać poszczególne objawy z obecnością konkretnej choroby. Otóż w pierwszym wydaniu nadpobudliwość określono jako minimalną dysfunkcję mózgu, w 1968 jako „hiperkinetyczną reakcję dziecięcą”, natomiast w 1980 r. dysfunkcja awansowała już na pełnoprawne zaburzenie - zespół zaburzeń koncentracji uwagi bez lub z nadpobudliwością ruchową. W kolejnych wydaniach z lat 1987 i 1994 nadpobudliwość oficjalnie dodano do definicji zaburzenia, przemianowując ją na „zespół nadpobudliwości psychoruchowej z deficytem uwagi (ADHD) z trzema podgrupami: z przewagą deficytu uwagi, z przewagą zachowań nadaktywno-kompulsywnych i mieszany"4. Na wszystkie te odmiany przemysł farmaceutyczny oczywiście opracował odpowiednie leki.

Innym chwytem stosowanym wobec pacjentów jest - jak to określają fachowcy - „kreowanie marki choroby”. Przemianowanie zwykłej zgagi na poważnie brzmiącą „chorobę refluksową przełyku” (GERD) pozwoliło koncernowi Glaxo do chwili wygaśnięcia patentu na Zantac w 1997 r. sprzedać lek na receptę 240 milionom osób.

3 Tamże, s. 72.

4 Tamże, s. 91-92. 
Obecnie wiemy już, że jesteśmy osobami dotkniętymi licznymi dolegliwościami, które dzięki postępowi nauki można leczyć środkami farmakologicznymi. Wśród nich znajdujemy: zespół chronicznego zmęczenia, zaburzenia obsesyjno-kompulsywne, zespół stresu pourazowego, zespół jelita drażliwego, zespół metaboliczny, sezonowe zaburzenia nastroju oraz różne fobie czy lęki (np. przed straceniem okazji podczas wyprzedaży). Kolejnym etapem rozwoju rynku leków stało się leczenie osób z tzw. grupy ryzyka. Czyli, mówiąc jednym słowem, każdego człowieka. W rezultacie przeciętny członek naszego społeczeństwa zażywa niezliczone leki, niepotrzebnie zatruwając swój organizm i żyjąc w swego rodzaju paranoi. Gdy dopadnie nas na skutek nieprawidłowego odżywiania zgaga (przepraszam - zespół GERD) lub ból żołądka, nie musimy iść do lekarza ani zmienić diety, tylko łyknąć pastylkę. Powoli na skutek prowadzonych wobec społeczeństw manipulacji socjologicznych doprowadzono do przekonania, że lekiem na wszelkie zło nie jest porada lekarska, ale kolorowa tabletka.

Kolejne rozdziały poświęcono umowom, które odmieniły nasze życie, wykorzystując do tego celu świat cyberprzestrzeni. Jeden z fragmentów pracy omawia kwestie stopniowej eliminacji z życia gospodarczego fizycznej formy pieniądza w celu zarabiania na transakcjach przeprowadzanych w Internecie. Pretekstem do jego napisania stała się umowa podpisana 12 VIII 2002 r. Właściciel eBaya Pierre Omidyar zakupił wówczas od Petera Thiela, Elona Muska i Maxa Levchina serwis PayPal. Transakcja ta umożliwiła stworzenie pierwszej, wartej miliard dolarów platformy do transakcji internetowych i stała się impulsem do zrewolucjonizowania tradycyjnej formy handlu. U źródeł sukcesu tej formy zawierania transakcji leżało wyeliminowanie u potencjalnych nabywców bardzo przykrego (i opisanego przez psychologów) uczucia rozstawania się z realną gotówką. Tym samym skłoniono wielu konsumentów do nieodpowiedzialnego wydawania pieniędzy. Jednak skutki tej transakcji są daleko bardziej znaczące, niż to się wydaje na pierwszy rzut oka. Przede wszystkim był to bardzo ważny krok na drodze ku odebraniu bankom, a nawet rządom kontroli nad pieniędzmi obywateli i przekazaniu ich w ręce nowych graczy, jakimi stały się firmy technologiczne ${ }^{5}$. Sukces eBaya rozpoczął nową erę rywalizacji o zdominowanie handlu w cyberprzestrzeni.

Wkrótce na rynku sprzedaży internetowej pojawił się poważny konkurent. Gdy w 2007 r. Apple wprowadził na rynek nowy produkt iPhone, zapowiadano, że odmieni on świat, ponieważ będzie zawierał w sobie telefon, odtwarzacz muzyki i mo-

5 Tamże, s. 103. 
bilny nawigator po Internecie. Początkowo nie planowano pozwalać na wykorzystywanie go przez aplikacje będące wytworem programistów spoza firmy. Zamierzano w pełni kontrolować swój produkt. Jednak Steve Jobs bardzo szybko przekonał się, że takie aplikacje pozwolą zwiększyć potencjał iPhone’a i dlatego zmieniono strategię firmy. Już w 2008 r. ruszył AppStore - internetowy sklep z różnorodnymi aplikacjami. Dzisiaj jest to źródło gigantycznych dochodów. Tylko 1 I 2017 r. użytkownicy Apple pobrali „towaru” za $240 \mathrm{mln} \${ }^{6}$. Odtąd człowiek nie rozstaje się z nowym urządzeniem, które ułatwia pracę, zapewnia rozrywkę i kontakt niemal z całym światem.

Wkrótce koncern $\mathrm{z}$ jabłuszkiem $\mathrm{w}$ herbie ponownie zrewolucjonizował rynek sprzedaży internetowej, ale tym razem skupił się na zgoła innym aspekcie związanym $\mathrm{z}$ transakcjami handlowymi. Krokiem w tym kierunku stało się podpisanie kolejnej umowy odmieniającej nasze życie. 9 IX 2014 r. Apple sfinalizował projekt, przygotowywany od roku w ścisłej tajemnicy. Latem 2013 r. firma zwróciła się do pięciu głównych banków i spółek American Express, Mastercard oraz Visa z propozycją wspólpracy. Liczono na uzyskanie ich wsparcia dla tworzonej infrastruktury Apple Pay. W trakcie przygotowywania projektu nawiązywano współpracę ze wszystkimi liczącymi się instytucjami finansowymi. W dniu ogłoszenia nowego produktu Apple wywołał prawdziwe trzęsienie ziemi, bowiem jego pojawienie się sprawiło, że tradycyjne karty płatnicze zaczęły tracić na znaczeniu. Wspomniane porozumienia nie tylko zrewolucjonizowały handel i finanse w skali globalnej. Z jednej strony ich dobrodziejstwo szczególnie dało się zauważyć w dobie pandemii, z drugiej - trzeba pamiętać, że niosą one ze sobą poważne zagrożenia, których do dzisiaj ani konsumenci, ani politycy nie są w pełni świadomi.

Większość wielkich firm technologicznych zarabia ogromne pieniądze jedynie na sprzedaży urządzeń obsługujących takie transakcje. Dzięki temu obroty handlowe w Internecie nie są obarczone kosztami ich obsługi. Firmy technologiczne, oferując ułatwienia w tego typu kontaktach handlowych, zagospodarowały dotychczas niedostrzeganą przestrzeń, jaka istnieje pomiędzy kupującym a sprzedającym. Jednak nasza aktywność handlowa jest pilnie obserwowana przez firmy zajmujące się zbieraniem informacji o naszych nawykach i upodobaniach. Informacje takie są niezwykle cenne dla handlujących, którzy dzięki nim mogą bardzo szybko rozpoznać nasze preferencje i dotrzeć ze swoją ofertą do wykorzystywanych przez nas stron internetowych. W tej sytuacji zrozumiały wydaje się przypomniany przez Perettiego

6 E. Bendyk, Super gadżet wszechczasów. Jak iPhone zmienit świat, https://www.polityka. pl/tygodnikpolityka/nauka/1711492,1,supergadzet-wszech-czasow-jak-iphone-zmienil-swiat. read [dostęp: 4 VI 2021]. 
przykład, gdy firmy handlowe, korzystając z analizy aktywności młodocianej internautki, dowiedziały się szybciej o jej ciąży niż biologiczny ojciec.

Prawdopodobnie ograniczona objętość publikacji nakazała Autorowi tylko symbolicznie wspomnieć o innych zagrożeniach wynikających z obserwacji naszych zachowań w cyberprzestrzeni. Pojawienie się nowej przestrzeni, z której każdego dnia korzystamy, naraża nas na inne niebezpieczeństwo. Używanie przeglądarek stron internetowych, aktywny udział w życiu różnego rodzaju mediów społecznościowych czy dokonywane transakcje handlowe sprawiają, że instytucje analizujące nasze zachowania uzyskują o nas nieograniczony zasób informacji. To, przy pomocy odpowiednich zabiegów socjotechnicznych, umożliwia sterowanie naszymi zachowaniami w sposób pożądany dla różnych grup społecznych czy politycznych. Ankietowe badania przeprowadzone wśród internautów wykazały, że nie są oni zainteresowani tym problemem. Tymczasem ostatnie lata przekonały nas, że zdobyta wiedza o upodobaniach internautów może być użyta do sterowania nastrojami społecznymi na niespotykaną dotąd skalę. Drastycznym przykładem nieograniczonych możliwości manipulacyjnych mogą być działania podjęte przez Cambridge Analytica. Mające kontakty z rosyjskimi koncernami konsorcjum brytyjskie na podstawie zdobytych legalną oraz nielegalną drogą danych o użytkownikach stron internetowych i forum społecznościowych wykryło, że osobowość konkretnego człowieka można określić na przykład na podstawie jego profilu na Facebooku. Korzystając z uzyskanych danych, pracownicy firmy wpłynęli na wyniki wyborów prezydenckich na wyspach Saint Kitts i Nevis, a w późniejszym czasie w Nigerii. Zdobyte doświadczenie Cambridge Analytica wykorzystała do sterowania preferencjami wyborczymi Brytyjczyków w czasie referendum w sprawie Brexitu oraz do manipulowania niezdecydowanymi wyborcami na korzyść Donalda Trumpa w czasie amerykańskich wyborów prezydenckich w 2016 r. ${ }^{7}$ Istnieją uzasadnione podejrzenia, że działania Brytyjczyków mogły być sprowokowane i wykorzystane przez podmioty rosyjskie, które na szeroką skalę prowadzą wrogie działania w cyberprzestrzeni w stosunku do wielu państw. Tu na czoło wysuwa się mająca siedzibę w Petersburgu Agencja Badań Internetowych, czyli tzw. „fabryka trolli”.

Peretti ukazał w swojej książce ewolucję światowej gospodarki w ostatnich trzydziestu latach, w których zarówno rozwój techniki, jak i właściwości dynamicznie rozwijającej się cyberprzestrzeni pozwoliły państwom (a raczej globalnym koncernom) na stworzenie systemu kontroli obywateli na niespotykaną do tej pory skalę.

7 Ch. Wylie, Mindf*ck. Cambridge Analytica, czyli jak popsuć demokrację, Kraków 2020. 
W latach czterdziestych George Orwell roztoczył przed czytelnikami wizję komunistycznego państwa totalitarnego, w którym nie tylko działania obywatela, lecz także jego myśli były w całości kontrolowane przez różnego rodzaju instytucje. Prawdopodobnie nikt nie spodziewał się tego, że do stworzenia opisywanej przez pisarza rzeczywistości dojdzie w wyniku rozwoju technologii i ewolucji kapitalistycznego systemu gospodarczego w cieniu funkcjonujących demokratycznych instytucji państwowych.

W pracy Perettiego przerażająca jest jeszcze jedna konstatacja. Doświadczenia ostatnich dekad pokazują, że najbardziej efektywnym systemem gospodarczym jest ten, w którym udało się społeczeństwo podporządkować i wykorzystać do działań produkcyjnych. Może być nim dyktatorskie państwo - jak w przypadku Chin - bądź konsorcjum - jak w Japonii, Korei Południowej czy Tajwanie.

Lektura książki Perettiego skłania do wielu refleksji. Ukazuje ona, w jak wielkim stopniu upowszechnienie Internetu zmieniło każdy aspekt naszego życia. Wizjonerskie koncepcje nie tylko wywrócily do góry nogami tradycyjny handel, bankowość czy systemy komunikacyjne, lecz także mają niebagatelny wpływ na nasze zachowania społeczne. Dostęp do sieci gwarantuje kontakt ze światem bez opuszczania domu. $\mathrm{Z}$ jednej strony stanowi to bardzo dużą wygodę, możliwość uczestnictwa $\mathrm{w}$ procesie produkcyjnym z niemal każdego zakątka ziemi, a z drugiej - zmienia tryb życia i zachowania społeczne. Nawet najmilszy kontakt online z drugą osobą nigdy nie zastąpi rozmowy „w cztery oczy”. Spędzając coraz więcej czasu przy komputerze, Smartfonach czy iPhone’ach, młode pokolenie stopniowo zatraca umiejętności współżycia społecznego, poznawania emocji drugiej osoby po mimice, „mowie ciała”, intonacji wypowiadanych słów. Tracimy sposobność czerpania radości z bycia razem, wspólnego przebywania w bezpośredniej bliskości, wymiany myśli, uczuć, gestów itp. Przekłada się to bezpośrednio na umiejętności tworzenia trwałych związków z drugą osobą, wspólnego pokonywania trudności i dzielenia radości życia - nie mówiąc już o wspólnym wychowywaniu dzieci. Najmniejsze problemy, które stają przed takimi osobami, doprowadzają najczęściej do rozejścia się życiowych dróg niedojrzałych partnerów. Normą stają się również doraźne związki, które w krótkim czasie ulegają rozpadowi. Powoli stajemy się zbiorowiskiem samotników i indywidualistów.

W efekcie tych procesów w społeczeństwach rozwiniętych rozpoczął się proces zaniku tradycyjnych form życia społecznego. Wydłużający się czas przebywania w pracy, korporacje starające się w pełni wypełniać czas wolny pracowników, organizując na przykład imprezy integracyjne, coraz częściej stają na przeszkodzie budowaniu tradycyjnych form życia (problemy motywowania pracowników do większej 
wydajności, funkcjonowania „opiekuńczych korporacji” oraz „kult lojalności” Peretti poruszył w rozdziale piątym). Jeżeli dodamy do tego coraz atrakcyjniejsze możliwości spędzania wolnego czasu w samotności i lansowaną na każdym kroku modę na zdrowe, radosne i pozbawione problemów życie, to trudno się dziwić, że coraz większy odsetek członków społeczeństw rozwiniętych wybiera życie w samotności lub odwleka decyzję o założeniu rodziny. W ślad za tym zmniejsza się także liczba rodzonych dzieci, co w przyszłości musi przełożyć się na trwałość dotychczasowych systemów funkcjonujących w państwie - na przykład systemu emerytalnego.

Osobnym problemem jest pojawienie się nowych schorzeń zarówno fizycznych (np. wady postawy, wady wzroku), jak i psychicznych. I nie chodzi w tym momencie o te wypracowane w gabinetach firm farmaceutycznych. Warto zwrócić uwagę na to, że człowiek jest stworzony do życia we wspólnocie. Samotność, brak możliwości dzielenia się radościami i problemami życiowymi, wymusza samodzielne pokonywanie problemów, a często odbija się na stanie psychicznym tzw. singli. Stąd rośnie zapotrzebowanie na porady psychologów i psychiatrów, a depresja dotyka coraz młodszych ludzi. Często spotkania z psychologami czy w grupach terapeutycznych zastępują jeszcze nie tak dawne spotkania i wsparcie grupy dobrych przyjaciół.

Niezwykle szybkie i wszechogarniające zmiany, jakim podlega nasze życie w ostatnich dekadach, zaprowadziły społeczeństwa państw wysokorozwiniętych w ślepą uliczkę. W dzisiejszych czasach dysponują one wspaniałymi i nowatorskimi narzędziami, umożliwiającymi dokonywanie odkryć na niespotykaną dotąd skalę. Jednak niepokój budzi to, że w ślad za tymi odkryciami nie nadąża refleksja filozoficzna nie tylko nad - wydawać by się mogło - nieograniczonymi możliwościami człowieka, ale również nad dalekosiężnymi skutkami naszych działań. Dotychczasowe koncepcje określające cel i zasady życia wśród problemów, które stawia przed nami szybko rozwijająca się cywilizacja, z dnia na dzień stały się anachroniczne. Problem, który w zasadzie dotyczy wszystkich nurtów filozoficznych najlepiej ilustruje kryzys kościołów chrześcijańskich. Krótkotrwałym przebłyskiem mógł być pontyfikat Jana Pawła II, który w udanej formie starał się zwrócić uwagę na poszanowanie potrzeb duchowych człowieka, przypominając zarazem, że z życiem człowieka nieodłącznie związane są również ból i cierpienie. Papież z Polski nie tylko potrafil na nowo zdefiniować miejsce i rolę Kościoła katolickiego w stającym w obliczu nowych wyzwań społeczeństwie, lecz także umiał dotrzeć ze swoją propozycją do szerokiej rzeszy wiernych. Jednak w nowym tysiącleciu brakuje osób, które mogłyby jak Leon XIII zaproponować encyklikę na miarę Rerum Novarum, czy - jak Jan XXIII - rzucić hasło „trzeba przewietrzyć Kościół” i zwołać Drugi Sobór Watykański. 
Odnosi się wrażenie, że współczesny człowiek, żyjąc w totalnym chaosie, został pozostawiony bez żadnych wskazówek, w jaki sposób sobie z nim radzić. Współczesny świat społeczeństw wysokorozwiniętych poza dobrami materialnymi nie ma człowiekowi nic więcej do zaoferowania. Tu pewnie należy szukać przyczyn sukcesu akcji werbowania młodych muzułmanów, dzieci emigrantów osiedlających się w Europie Zachodniej, do oddziałów ISIS.

Peretti, przytaczając dziesięć przykładów zmian, które w znaczący sposób wpłynęły na obraz świata, zasygnalizował jedynie problem, z którym musi się zmierzyć nasza cywilizacja. Jednak jego zakres jest znacznie szerszy. Na przykład rozwój technologii pozwalający na redukcje kosztów wytwarzania wraz z pogarszaniem jakości kupowanych przez nas sprzętów zmienił całkowicie nasze nawyki. Obecnie zużyty/ zepsuty sprzęt wyrzuca się na wysypisko i kupuje nowy. Tym samym bezużyteczni stali się szewcy, właściciele warsztatów naprawy sprzętu RTV itp. Bardzo często koszty naprawy uszkodzonych zmywarek, telewizorów czy ekspresów do kawy są tak wysokie, że bardziej opłaca się zainwestować w kolejny model niż szukać możliwości naprawy starego. Takie praktyki niosą ze sobą bardzo niebezpieczne następstwa. W zastraszający sposób bowiem zaczęła rosnąć ilość śmieci. Konsumpcyjny styl życia stawia społeczności wysokorozwinięte przed problemem zagospodarowania tych odpadów. I nie są to jedynie zużyte sprzęty, ale również wszelkiego rodzaju opakowania produkowane najczęściej z tanich tworzyw sztucznych. Lansowane przez wielkie koncerny różnego rodzaju „mody” i „kolekcje” powodują, że przestarzałe (najczęściej z zeszłego roku) przedmioty lądują na śmietnikach tylko dlatego, że nie pasują do aktualnie dyktowanych trendów mody. Proces ten inicjuje jeszcze inne problemy o charakterze ekologicznym, które tu zostaną pominięte.

Podczas lektury pracy Perettiego nasuwa się jeszcze jedna refleksja. Nieustanna pogoń za zyskiem doprowadziła do całkowitej komercjalizacji wszystkich sfery życia. W ostatnich latach zjawisko to dotknęło również szeroko rozumianą rozrywkę oraz coraz większą liczbę rozgrywek sportowych. Rewolucyjne zmiany zaszły na rynku muzycznym szczególnie w latach osiemdziesiątych, gdy na półkach sklepowych zaoferowano płyty $\mathrm{CD}$, a w telewizji pojawily się komercyjne kanały muzyczne MTV, VIVA, VH-1 i inne. W ostatnich czterech dekadach koncerny muzyczne zmonopolizowały rynek muzyczny do tego stopnia, że przestały zabiegać o podpisanie kontraktów z utalentowanymi muzykami, ale same decydują o lansowanych trendach muzycznych i promują zespoły, które gwarantują dochody na odpowiednim poziomie. Komponowanie muzyki w coraz mniejszym stopniu stawało się procesem twórczym, a coraz częściej było produktem, który musi ukazać się w okresie przed- 
świątecznym na półkach sklepowych, by osiągnąć wymierny wynik komercyjny. Młodzi twórcy coraz rzadziej mają swobodę twórczą i właściwie nagrywają piosenki pod dyktando narzuconych przez wytwórnie płytowe producentów i inżynierów dźwięku. Podobne procesy daje się zauważyć również w filmie, gdzie o ocenie filmu coraz częściej decyduje poziom zysków osiągniętych w pierwszym weekendzie emisji w kinach.

Analogiczne procesy można zauważyć w sporcie. Szczytne ideały Pierre’a de Coubertina, wskrzesiciela idei olimpiad, coraz częściej przegrywają z merkantylnym charakterem wielkich widowisk sportowych. Zarówno Igrzyska Olimpijskie, jak i mistrzostwa świata w piłce nożnej czy lekkiej atletyce, stały się wielkimi i dochodowymi imprezami, na których piękno rywalizacji sportowej ustępuje wpływom $\mathrm{z}$ reklamy. Zmiany w przepisach umożliwiające uatrakcyjnienie zawodów dotknęly siatkówkę czy konkursy w skokach narciarskich. Drużyny piłkarskie coraz częściej stają się wielkimi przedsiębiorstwami mającymi zapewniać dochody na odpowiednim poziomie. W najbogatszych klubach podpisuje się kontrakty nie tylko z piłkarzami dobrze grającymi w piłkę, ale również z takimi, którzy zagwarantują sprzedaż koszulek klubowych z własnym nazwiskiem na odpowiednim poziomie i stworzą odpowiednie strony internetowe. Wiele klubów w letniej przerwie rozgrywkowej udaje się na komercyjne tournée po Chinach czy Stanach Zjednoczonych. Warto przypomnieć, że w ostatnich tygodniach europejską opinią publiczną wstrząsnęła informacja o kolejnej próbie stworzenia przez najbogatsze kluby europejskie Superligi. James Montague, angielski dziennikarz i autor książek o zmianach w piłce nożnej w dobie przejmowania klubów przez miliarderów, zwraca uwagę na to, że proces komercjalizacji piłki nożnej doprowadził do upadku rodzinnego kibicowania na angielskich stadionach. Nowi właściciele traktują inwestycje w kluby sportowe jak biznes. Ważniejsza niż bezgraniczna czasem sympatia i oddanie rzesz identyfikujących się z klubem kibiców jest możliwość sprzedania drogich miejscówek japońskim turystom. Najwierniejsi kibice drużyny miejscowej oglądają mecze swoich ulubieńców w pobliskich pubach, bowiem kibic stał się jedynie klientem, który musi wykupić klubowe gadżety i bilet na mecz ${ }^{8}$. Według Montague trendu tego nie można już zatrzymać i idea utworzenia Superligi prędzej powróci, ponieważ będzie ona kolejną możliwością zarobienia dużych pieniędzy. Piłkarscy giganci nie chcą już potykać się w szlachetnej rywalizacji z prowincjonalnymi klubami.

8 M. Wawrzynowski, Temat Superligi powróci? „Nie cieszmy się przedwcześnie”, https:// sportowefakty.wp.pl/pilka-nozna/935842/nie-cieszmy-sie-przedwczesnie-superliga-powroci, [dostęp: 24 V 2021]. 
Praca Perettiego jest przyczynkiem pozwalającym uzmysłowić sobie głębokość zmian, jakie dotknęły nasze społeczeństwo w ostatnich trzech dekadach. Pojawienie się Internetu popchnęło rozwój cywilizacyjny na nowe tory. Już w tej chwili są one tak znaczące, że wszystkich skutków nie jesteśmy w stanie przewidzieć. Największym problemem jest jednak to, że zarówno szeregowi obywatele, jak i politycy nie zdają sobie sprawy z charakteru zachodzących przemian, a brak rozeznania w tej materii może skutkować poważnymi reperkusjami politycznymi i gospodarczymi. Jaką refleksję wzbudza książka Perettiego u mnie? Ujmując to jednym zdaniem: widzę potrzebę tworzenia zakładów historii współczesnej, które rozpoczną badania obejmujące swym zasięgiem historię powszechną i Polski ostatnich trzech dekad.

\section{Bibliografia}

Bendyk E., Super gadżet wszechczasów. Jak iPhone zmienit świat, https://www.polityka.pl/tygodnikpolityka/nauka/1711492,1,supergadzet-wszech-czasow-jak-iphone-zmienil-swiat.read.

Peretti J., Zakulisowe umowy, które zmienity świat. Niepohamowane ambicje, tajne negocjacje i skrywane prawdy w biznesie, Poznań 2019.

Wawrzynowski M., Temat Superligi powróci? „Nie cieszmy się przedwcześnie”, https:// sportowefakty.wp.pl/pilka-nozna/935842/nie-cieszmy-sie-przedwczesnie-superliga-powroci.

Wylie Ch., Mindf*ck. Cambridge Analytica, czyli jak popsuć demokrację, Kraków 2020.

Nadesłany: 8 VI 2021

Zaakceptowany: 14 VI 2021

Dr hab. Piotr Okulewicz, prof. UAM

Uniwersytet im. Adama Mickiewicza w Poznaniu

Wydział Historii

ul. Uniwersytetu Poznańskiego 7

61-614 Poznań

e-mail: okulewicz@wp.pl 